\title{
Peningkatan Kadar Hemoglobin Remaja Putri dengan Pemberian Kukis Pelangi Ikan Gaguk (Arius thalassinus)
}

\section{Increased Hemoglobin Levels of Young Girls by Giving Rainbow Fish Cookies (Arius thalassinus)}

\author{
Dwi Putri Cahyati ${ }^{1}$, Betty Yosephin Simanjuntak ${ }^{2}$, Ahmad Rizal $^{3}$ \\ Jurusan Gizi, Politeknik Kesehatan Kemenkes Bengkulu, Indonesia
}

\section{ARTICLE INFO}

\section{Article history}

Received date

19 August 2020

Revised date

24 August 2020

07 Sept 2020

Accepted date

23 Sept 2020

Keywords:

Arius thalassinus;

Cookies,

Hemoglobin level.

Kata kunci:

Arius thalassinus;

Kukis;

Kadar hemoglobin.

\author{
ABSTRACT/ ABSTRAK
}

\begin{abstract}
Women have a higher risk of anemia, especially in young women. This study aimed to determine the effect of giving the rainbow fish cookies (Arius thalassinus) to changes in hemoglobin levels in young girls in Pancasila MTs Bengkulu City. This study was a preexperimental design study with one group pretest and posttest design. The sampling technique was done by purposive sampling as many as 37 people. The treatment given is in the form of 10 pieces (100gr) rainbow fish cookies for 30 days to young women. This research was carried out by checking the levels of hemoglobin before and after the administration of the rainbow fish cookies. The analysis used is the dependent parametric T-test. The average recall of young women $3 \times 24$ hours was Fe intake by $5,40 \mathrm{mg}$, protein intake by 40,4 grams, and vitamin $\mathrm{C}$ intake by $5,7 \mathrm{mg}$. In the provision of cookies rainbow fish (Arius thalassinus) obtained an average value of hemoglobin levels before that is $10,70 \mathrm{~g} / \mathrm{dL}$ and after being given treatment to $12,87 \mathrm{~g} / \mathrm{dL}$ with a p-value of 0,000 $(<0,05)$. There is an effect of giving cookies rainbow fish to hemoglobin levels in young girls in Pancasila MTs Bengkulu City.
\end{abstract}

Perempuan memiliki risiko lebih tinggi mengalami anemia terutama pada remaja putri. Untuk mengetahui pengaruh pemberian kukis pelangi ikan gaguk (Arius thalassinus) terhadap perubahan kadar hemoglobin remaja putri di MTs Pancasila Kota Bengkulu. Penelitian ini merupakan penelitian pre-eksperiment design dengan rancangan one group pre-test dan post-test design. Teknik pengambilan sampel dilakukan dengan carapurposive sampling sebanyak 37 orang. Perlakuan yang diberikan yaitu berupa kukis pelangi ikan gaguk sebanyak 10 keping (100gr) selama 30 hari kepada remaja putri. Penelitian ini dilakukan dengan pengecekan kadar hemoglobin sebelum dan sesudah pemberian kukis pelangi ikan gaguk. Analisis yang digunakan adalah uji parametik T-test dependen. Rata-rata recall remaja putri $3 \times 24$ jam yaitu asupan $\mathrm{Fe}$ sebesar $5,40 \mathrm{mg}$, asupan protein sebesar 40,4 gram, dan asupan vitamin C sebesar 5,7mg. Pada pemberian kukispelangi ikan gaguk (Arius thalassinus) didapatkan nilai rata-rata kadar hemoglobin sebelum yaitu $10.70 \mathrm{~g} / \mathrm{dL}$ dan setelah diberikan perlakuan menjadi $12,87 \mathrm{~g} / \mathrm{dL}$ dengan nilai $p$-value $0,000(<0,05)$. Disimpulkan bahwa pemberian kukis pelangi ikan gaguk berpengaruh terhadap kadar hemoglobin remaja putri di MTs Pancasila Kota Bengkulu.

Corresponding Author:

Betty Yosephin Simanjuntak

Jurusan Gizi, Poltekkes Kemenkes Bengkulu, Indonesia

Email: patricknmom@yahoo.co.id

\section{PENDAHULUAN}

Hemoglobin merupakan bagian dari sel darah merah untuk menentukan adanya status anemia. Di dalam tubuh dibutuhkan zat besi untuk pembentukan hemoglobin. Jika cadangan zat besi kosong, maka pembentukan hemoglobin akan terganggu. Salah satu terjadinya anemia yaitu akibat dari kadar hemoglobin di bawah normal. Nilai normal kadar hemoglobin pada wanita yaitu 12-16 g/dL (Adriani \& Wirjatmadi, 2012). 
Perempuan beresiko lebih tinggi mengalami anemia, terutama pada remaja putri. Gejala dari anemia yaitu tejadinya defisiensi besi yang mengakibatkan pengangkutan oksigen dalam darah yang di tandai dengan mudah lelah, lemah, lesu, muka pucat, kurang selera makan, kuku mudah pecah, tidak konsentrasi belajar dan memperlambat daya tangkap pada anak usia sekolah (Dona, 2014).

Terjadinya anemia dapat diakibatkan dari beberapa faktor, yaitu menstruasi atau kecelakaan, cacingan atau penyakit infeksi, dan kurangnya asupan zat gizi teritama zat besi dan zat lain yang dapat meningkatkan penyerapan zat besi yaitu vitamin $\mathrm{C}$ dan protein (Sediaoetama, 2010).

Simanjuntak (2006) mengemukakan bahwa sebanyak 144 anak sekolah anemia diberikan tablet besi 2 kali seminggu selama 12 minggu, setelah pemberian suplementasi tablet besi kejadian anemia pada anak sekolah menurun menjadi 17 anak, hal tersebut juga dipengaruhi oleh kebiasaan makan, konsumsi sumber zat besi hem, besar keluarga, dan pendidikan ibu.

World Health Organization (WHO) (2017) menyatakan bahwa sebagian besar orang yang tinggal di daerah tropis mengalami anemia sebanyak 1,62 miliar atau sebesar $24,8 \%$ dari jumlah populasi. Angka anemia remaja putri sudah mengkhawatirkan, di Asia sudah mencapai 191 juta orang dan Indonesia merupakan urutan ke-8 dari 11 negara di Asia setelah Sri Lanka dengan penderita anemia sebanyak 75 juta orang pada usia 10-19 tahun (WHO, 2011).

Prevalensi anemia di Indonesia masih cukup tinggi. Dari data Riskesdas 2018 prevalensi anemia di pada WUS sebesar 48,9\%. Anemia lebih banyak terjadi pada perempuan, yaitu sebesar 23,9\%. Jika dibedakan menurut umur 1415 tahun, yaitu sebesar 26,4\% (Kementerian Kesehatan RI, 2013).

Jaelani, dkk (2017) mengemukakan prevalensi anemia remaja putri di MTsN 02 Kota Bengkulu, yaitu sebesar $33,0 \%$ dari 100 orang. Tingginya prevalensi anemia pada remaja putri dipengaruhi oleh beberapa faktor, yaitu kebiasaan sarapan pagi, status gizi, asupan protein, pola konsumsi makanan inhibitor, penyerapan zat besi, dan lama haid.

Kukis merupakan produk pakan kering yang tergolong tidak mudah rusak dan memiliki daya umur simpan yang relatif lama. Kukis dapat menjadi alternatif pemenuhan keanekaragaman makanan dan menjadi salah satu makanan selingan bagi penderita anemia (Indrawani, 2010).
Formulasi kukis kaya gizi yang disubstitusi dengan bahan pangan hewani dan bahan pangan nabati tersusun dari berbagai sumber bahan makanan yaitu daging ayam, daging sapi, terigu, ikan tuna, tempe, pisang, brokoli, bekatul, margarin, mentega dan telur diharapkan dapat memberi sumbangan makro dan mikronutrien seperti kalori, zat besi (Fe), vitamin C, Zink (Zn) dan kalsium $(\mathrm{Ca})$. Mineral yang terkandung berfungsi meningkatkan absorpsi Fe. Peningkatan tersebut akan meningkatkan sel darah merah. Fungsi sel darah merah yaitu untuk transportasi oksigen karbondioksida, zat gizi, mineral dan air. Pemberian kukis kaya gizi ini diharapkan mampu menurunkan kejadian anemia (Indrawani, 2010).

Ikan gaguk (Arius thalassinus) merupakan ikan yang hidup di daerah perairan laut, dengan hasil tangkapan yang cukup berlimpah. Harga ikan gaguk cukup ekonomis untuk dijangkau oleh kalangan masyarakat (Febrianti, 2013).

Lailiyana (2012) mengungkapkan bahwa kukis kaya gizi tuna dan non tuna, perkepingnya memiliki berat 10gram, 100gram kukis terdiri dari 10 keping. Nilai gizi energi 100gram kukis pada tuna yaitu 501,61kkal dan non tuna 497,79kkal. Kedua jenis kukis kaya gizi ini mengandung kalori antara 49,78-50,16kkal. Agar memenuhi $10 \%$ dari kebutuhan energi pada remaja (235kkal), sehingga takaran saji kukis kaya gizi sebagai makanan selingan yaitu 4-5 keping per saji.

Quintero, et al (2012) menunjukkan bahwa konsumsi regular biskuit cokelat sebanyak 6 keping/hari yang diperkaya dengan besi-heme dengan $9,5 \mathrm{mg}$ zat besi secara signifikan dapat meningkatkan konsentrasi hemoglobin pada remaja putri setelah 13 minggu (65 hari).

Tujuan penelitian ini untuk mengetahui pengaruh pemberian kukis pelangi ikan gaguk terhadap perubahan kadar hemoglobin remaja putri di MTs Pancasila Kota Bengkulu.

\section{METODE}

Desain penelitian ini adalah preeksperiment design dengan rancangan one group pre-test dan post-test design. Teknik pengambilan sampel dilakukan dengan cara purposive sampling.Populasi dalam penelitian ini adalah remaja putri yang bersekolah di MTs Pancasila Kota Bengkulu. Jumlah populasi dalam penelitian ini sebanyak 77 orang. Sampel dalam penelitian ini adalah siswi yang kadar hemoglobin $<12 \mathrm{~g} / \mathrm{dL}$ di MTs Pancasila Kota Bengkulu. Besar sampel berjumlah 37 responden. 
Perlakuan yang diberikan yaitu berupa kukis pelangi ikan gaguk sebanyak 100gr/10keping/hari selama 1 bulan (30 hari) kepada remaja putri. Penelitian ini dilakukan dengan pengecekan kadar hemoglobin sebelum dan sesudah pemberian kukis pelangi ikan gaguk. Metode pengukuran dilakukan oleh pihak analis kesehatan untuk mengumpulkan data hemoglobin dengan alat Easy Touch GCHb.

Monitoring kepatuhan remaja putri dalam mengonsumsi kukis dilakukan dengan cara yaitu menghitung/menimbang jumlah kukis yang tersisa. Pengambilan recall 3x24 jam, yaitu pada awal intervensi, pertengahan, dan diakhir intervensi. Penelitian ini dilakukan pada 2 tempat yaitu Laboratorium Gizi Poltekkes Kemenkes Bengkulu, MTs Pancasila Kota Bengkulu pada Februari-Maret 2020

Analisis data menggunakan uji kenormalan kolmogorv-smirnov test pada variabel kadar hemoglobin, nilai ( $p$-value $>0,05)$ menunjukkan bahwa variabel berdistribusi normal, sehingga peneliti menggunakan uji parametik T-test dependen.

Penelitian ini sudah mendapatkan uji laik etik dan memperoleh Persetujuan Etik (Ethical Approval) dengan No.KEPK.M/100/04/2020 oleh Komite Etik Penelitian Kesehatan Politeknik Kesehatan Kemenkes Bengkulu.

\section{HASIL}

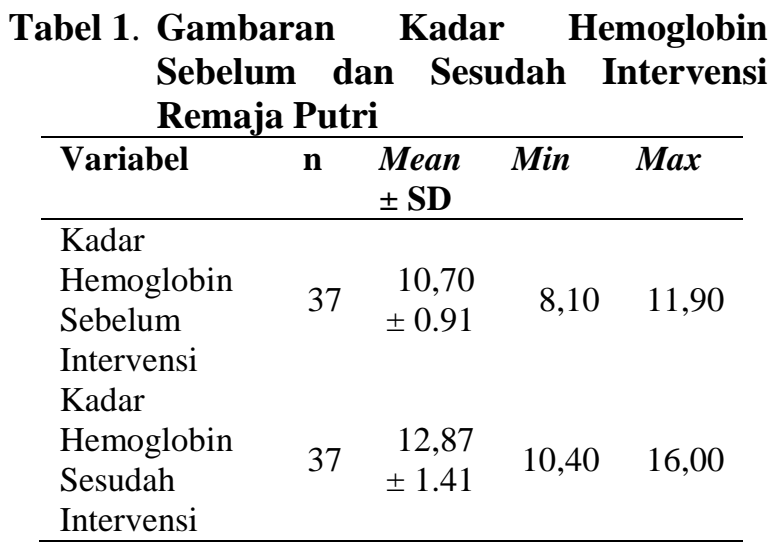

Rata-rata kadar hemoglobin mengalami kenaikan, yaitu kadar hemoglobin sebelum intervensi $10,70 \mathrm{~g} / \mathrm{dL}$. Sesudah intervensi naik menjadi $12,87 \mathrm{~g} / \mathrm{dL}$, sehingga mengalami kenaikan sebesar $2,17 \mathrm{~g} / \mathrm{dL}$.
Tabel 2.Distribusi Asupan Fe, Vitamin C dan Protein pada Remaja Putri

\begin{tabular}{lrrr}
\hline \multicolumn{1}{c}{$\begin{array}{c}\text { Variabel } \\
\text { Asupan }\end{array}$} & Mean & \multicolumn{1}{c}{ Min } & \multicolumn{1}{c}{ Max } \\
\hline Fe (mg) & 5,40 & 3,78 & 7,20 \\
Vitamin C (mg) & 5,7 & 4,10 & 11,10 \\
Protein (g) & 40,4 & 32,63 & 52,30 \\
\hline
\end{tabular}

Rata-rata hasil recall 3x24 jam didapatkan asupan $\mathrm{Fe}$, yaitu sebesar 5,40mg, asupan vitamin $\mathrm{C}$ sebesar $5,7 \mathrm{mg}$ dan asupan protein sebesar 40,4gram.

\begin{tabular}{|c|c|c|c|c|}
\hline $\begin{array}{l}\text { Ika } \\
\text { Her }\end{array}$ & & $\begin{array}{l}\text { uk terh } \\
\text { Remaja }\end{array}$ & $\begin{array}{l}\text { dap } \\
\text { Itri }\end{array}$ & Kadar \\
\hline Variabel & $\mathbf{n}$ & Min-Max & $\begin{array}{c}\text { Mean } \\
\pm \text { SD } \\
\end{array}$ & $\begin{array}{c}p- \\
\text { value }\end{array}$ \\
\hline $\begin{array}{l}\text { Kadar } \\
\text { Hemoglobin } \\
\text { Sebelum } \\
\text { Intervensi }\end{array}$ & 37 & $\begin{array}{l}(8,10- \\
11,10)\end{array}$ & $\begin{array}{r}10,70 \\
\pm \\
0,91\end{array}$ & \multirow{2}{*}{0,000} \\
\hline $\begin{array}{l}\text { Kadar } \\
\text { Hemoglobin } \\
\text { Sesudah } \\
\text { Intervensi }\end{array}$ & 37 & $\begin{array}{r}(10,40- \\
16,00)\end{array}$ & $\begin{array}{r}12,87 \\
\pm \\
1,41\end{array}$ & \\
\hline
\end{tabular}

Hasil uji statistik t-test dependentdengan nilai p-value $(0,000)$, yang berarti terdapat perbedaan kadar hemoglobin sebelum dan sesudah pemberian kukis. Sehingga dapat disimpulkan bahwa ada pengaruh pemberian kukis pelangi ikan gaguk terhadap kadar hemoglobin remaja putri di MTs Pancasila Kota Bengkulu tahun 2020.

\section{PEMBAHASAN}

\section{Gambaran Kadar Hemoglobin Sebelum dan Sesudah Intervensi Remaja Putri}

Penelitian ini menemukan bahwa terjadi peningkatan rata-rata nilai kadar hemoglobin setelah intervensi, yang menunjukkan dampak dari pemberian kukis. Jika pada pre-test rata-rata nilai kadar hemoglobin adalah sebesar $10,70 \mathrm{~g} / \mathrm{dL}$, maka setelah intervensi rata-rata kadar hemoglobin menjadisebesar $12,87 \mathrm{~g} / \mathrm{dL}$. Dengan demikian, dengan pemberian kukis, kategori hemoglobin dari anemia meningkat menjadi normal.

Pada pemeriksaan kadar hemoglobin pretest, didapat nilai minimal yaitu sebesar $8,1 \mathrm{~g} / \mathrm{dL}$ dan nilai maksimal yaitu sebesar $11,9 \mathrm{~g} / \mathrm{dL}$. Kemudian setelah pemberian kukis terjadi peningkatan kadar hemoglobin dengan nilai minimal sebesar $10,5 \mathrm{~g} / \mathrm{dL}$ dan nilai maksimal 
yaitu sebesar $16 \mathrm{~g} / \mathrm{dL}$. Dari pre-test yang dilakukan masih banyak anemia yang terjadi pada remaja putri. Ini sejalan dengan prevalensi anemia diIndonesia berdasarkan data Riskesdas Tahun 2018, yaitu mencapai 48,9\%. Dari data presentase perempuan mendominasi angka anemia sebesar $23,9 \%$ dan paling banyak pada umur 5-14 tahun yaitu 26,4\% (Kementerian Kesehatan RI, 2018).

Terjadinya peningkatan kadar hemoglobin sesudah pemberian kukis pelangi ikan gaguksejalan dengan yang ditemukan oleh Syahwal (2018), yaitu adanya peningkatan kadar hemoglobin remaja putri setelah diberikan snack bar dari tepung kacang nagara dan ikan haruan dengan kadar hemoglobin sebelum intervensi yaitu sebesar $11,65 \mathrm{~g} / \mathrm{dL}$ dan setelah intervensi mengalami peningkatan menjadi $12,69 \mathrm{~g} / \mathrm{dL}$.

Sesudah pemberian kukis, masih terdapat 8 responden dengan kadar hemoglobin $<12 \mathrm{~g} / \mathrm{dL}$. Sedangkan 29 responden sudah dikaterogikan normal yaitu $>12 \mathrm{~g} / \mathrm{dL}$. Ini dapat disebabkan bahwa penyerapan zat besi setiap orang berbeda, hal tersebut dipengaruhi oleh dietery regulator yaitu setelah pemberian besi, sel serap akan tahan terhadap penyerapan besi dalam beberapa waktu (Diah, 2019).

Kukis dapat menjadi salah satu makanan selingan atau tambahan bagi remaja putri. Selama pemberian rata-rata responden sudah menghabiskan kukis yang diberikan. Tingkat kepatuhan dalam mengkonsumsi kukis pelangi ikan gaguk sangat berpengaruh terhadap kadar hemoglobin remaja putri untuk pencegahan anemia. Setiap responden memiliki tingkat kepatuhan mengkonsumsi kukis yang berbedabeda, semakin patuh atau rutin responden maka ia akan semakin sadar bahwa pencegahan anemia sangat bermanfaat bagi kesehatan, dengan kesadaran ini maka akan membentuk suatu kepedulian khususnya pada kesehatan diri sendiri dalam melakukan pencegahan anemia.

Gambaran Asupan Fe, Vitamin C dan Protein Responden Selama Intervensi pada Remaja Putri

Selama intervensi peneliti melakukan recall 3x24 jam pada responden sehingga didapatkan nilai rata-rata asupan $\mathrm{Fe}$ sebesar 5,40mg, asupan vitamin $\mathrm{C}$ sebesar 5,7 $\mathrm{mg}$ dan asupan protein sebesar 40,4gram. Berdasarkan angka kecukupan gizi (AKG) 2019, asupan Fe, vitamin $\mathrm{C}$ dan protein yang dianjurkan pada perempuan usia 13-15 tahun yaitu $\mathrm{Fe} 15 \mathrm{mg}$, vitamin C $65 \mathrm{mg}$ dan protein 65 gram per hari. sehingga asupan $\mathrm{Fe}$, vitamin $\mathrm{C}$ dan protein pada responden masih dibawah kecukupan. Ketidakcukupan ini disebabkan oleh karena kurangnya kombinasi jenis makanan dan jumlah makanan yang dikonsumsi oleh responden di pondok pesantren. Asupan makanan yang dikonsumsi sehari-hari dapat memengaruhi kadar hemoglobin pada tubuh seperti $\mathrm{Fe}$, protein dan vitamin C. Hal ini sejalan dengan penelitian Setyaningsih (2018) yang menyatakan bahwa terdapat hubungan asupan protein, $\mathrm{Fe}$, dan Vitamin C terhadap kadar hemoglobin.

Pemberian kukis pelangi ikan gaguk sebanyak 100 gram/hari selama 1 bulan berpengaruh terhadap kadar hemoglobin. Hal ini dikarenakan rata-rata konsumsi kukis pelangi ikan gaguk sudah memenuhi hampir 50\% dari hasil recall $3 \times 24$ jam. Dengan hasil persentase asupan $\mathrm{Fe}$, vitamin $\mathrm{C}$ dan protein kukis pelangi ikan gaguk pada remaja putri dalam satu hari dibandingkan dengan rata-rata recall $3 \times 24$ jam, yaitu Fe sebesar 33\%, vitamin C sebesar 24,9\% dan protein $49,23 \%$.

Menurut Almatsier (2011) keasaman lambung dapat meningkatkan daya larut besi sehingga lebih mudah di absorpsi. Tingkat keasaman lambung memengaruhi kebutuhan zat besi dan ketersediaan biologis besi yang dikonsumsi. Status besi dalam tubuh dapat memengaruhi efisiensi penyerapan zat besi. Remaja putri dengan defisiensi zat besi maka penyerapannya akan lebih efisien dibandingkan yang tidak mengalami defisiensi zat besi (Maryam, 2016).

Zat besi memegang peranan penting dalam pembentukan darah (hemopoiesis) yaitu mensintesis hemoglobin. Absorpsi zat besi ini dapatdipercepat dengan adanya vitamin C. Vitamin ini merupakan unsur esensial yang sangat dibutuhkan oleh tubuh untuk pembentukan sel-sel darah merah. Pembentukan hemosiderin yang sukar dimobilisasi dapat dihambat oleh vitamin $\mathrm{C}$ untuk membebaskan besi bila diperlukan. Adanya vitamin $\mathrm{C}$ dalam makanan yang dikonsumsi akan memudahkan reduksi zat besi ferri menjadi ferro yang mudah diserap usus halus. Absorpsi zat besi dalam bentuk nonheme meningkat empat kali lipat bila terdapat vitamin C (Adriani dan Wirjatmadi, 2012).

Menurut Almatsier (2009) protein berperan penting dalam transportasi zat besi dalam tubuh, karena protein berfungsi sebagai energi, zat pembangun dan pengatur.

\footnotetext{
Pengaruh Pemberian Kukis Pelangi Ikan Gaguk terhadap Kadar Hemoglobin Remaja Putri
} 
Berdasarkan hasil uji statistik menunjukkan $p$-value 0,000 ( $p$-value $<0,05)$, artinya terdapat perbedaan yang signifikan antara kadar hemoglobin sebelum dan kadar hemoglobin sesudah. Sesudah pemberian kukis, terdapat 8 responden yang kadar hemoglobinnya dibawah normal, sedangkan 29 responden lainnya sudah dikategorikan normal. Rata-rata kadar hemoglobin sebelum intervensi sebesar $10,70 \mathrm{~g} / \mathrm{dL}$ dengan standar deviasi 0,91 . Sedangkan rata-rata kadar hemoglobin setelah intervensi sebesar $12,87 \mathrm{~g} / \mathrm{dL}$ dengan standar deviasi 1,41. Hasil uji statistik t-test dependent diperoleh nilai $p$-value $(0,000)$ maka dapat disimpulkan bahwa ada pengaruh pemberian kukis pelangi ikan gaguk terhadap kadar hemoglobin remaja putri di MTs Pancasila Kota Bengkulu tahun 2020.

Penelitian ini sejalan dengan Syahwal (2018) menyimpulkan bahwa pemberian snack bar tepung kacang nagara dan ikan haruan dapat meningkatkan kadar hemoglobin remaja putri. Penelitian ini dilakukan selama 1 bulan dengan pemberian snack bar tepung kacang nagara dan ikan haruan sebanyak 50gram 3 kali dalam seminggu, diperoleh hasil p-value 0,016 yang menunjukkan bahwa ada pengaruh pemberian snack bar yang terbuat dari daging ikan haruan dan kacang nagara terhadap kadar hemoglobin.

Berdasarkan perhitungan DKBM (Daftar Komposisi Bahan Makanan) Kandungan gizi kukis pelangi ikan gaguk dalam 10 keping atau 100 gram mengandung energi sebesar $363 \mathrm{kkal}$, protein 19,89gram, lemak 17,36gram, karbohidrat 31,63gram, Vit. C 1,42mg, Fe 1,78mg.

Pemberian kukis pelangi ikan gaguk selama 30 hari berpengaruh terhadap peningkatan kadar hemoglobin pada remajaputri. Ini dapat disebabkan karena sumber bahan utama dari pembuatan kukis yaitu dari daging ikan dan tempeyang merupakan sumber zat besi. Hasil penelitian Sari (2014) mengatakan bahwa zat besi dalam biskuit yang ditambahkan tepung ikan gabus mempunyai bioavailabilitas tertinggi yaitu sampai 76,32\%. selain sumber zat besi ikan juga merupakan sumber protein. Protein hewani yang terdapat pada ikan dapat meningkatkan penyerapan zat besi.

Pada penelitian Putri (2017) dari 100 responden sebanyak 37\% remaja putri mengalami anemia di MTsN 02 Kota Bengkulu. Ada hubungan pengetahuan gizi dengan status anemia $p$-value $=0,018(p$-value $<0,05)$ dan ada hubungan kepatuhan konsumsi tablet $\mathrm{Fe}$ dengan status anemia $p$-value $=0,0005$ ( $p$-value $<0,05)$. Namun, pada hasil penelitian ini tidak ada hubungan pola makan dengan status anemia pada remaja putri dengan hasil sumber protein $p$-value $=0,625$, sumber zat besi $p$-value $=0,708$, dan sumber vitamin C $p$-value $=1,000$ ( $p$-value $>0,05)$.

Pada penelitian Vitando (2019) hasil analisis nilai kadar protein ikan gaguk segar, yaitu $15,91 \%$. Setelah pembuatan tepung ikan dengan proses pengeringan pada suhu $150^{\circ} \mathrm{C}$ dalam waktu 120 menit menunjukkan hasil kadar protein, yaitu sebesar $71,52 \%$ dan pada suhu $200^{\circ} \mathrm{C}$ dengan waktu 90 menit menunjukkan hasil kadar protein, yaitu sebesar $72,67 \%$.

Protein berperan penting dalam transportasi zat besi dalam tubuh. jika tidak tersedia protein dalam jumlah cukup maka zat besi yang diasup tidak dapat didistribusikan dengan organ. Protein yang berfungsi untuk transportasi zat besi, yaitu transferin. Protein juga berperan sentral khususnya dalam metabolisme besi tubuh sebab transferin mengangkut zat besi dalam sirkulasi ke tempat-tempat yang membutuhkan zat besi, seperti dari usus ke sumsum tulang untuk membentuk hemoglobin baru (Sari, 2018).

Penelitian ini sejalan dengan Mansur (2017), diperoleh rerata kadar hemoglobin ibu hamil setelah pemberian brownis tempe selama 30 hari, yaitu 1,46g/dL dengan kadar hemoglobin sebelum pemberian $10,15 \mathrm{~g} / \mathrm{dL}$ dan mengalami peningkatan setelah tindakan pemberian menjadi $11,61 \mathrm{~g} / \mathrm{dL}$. Dapat disimpulkan bahwa brownis tempe efektif terhadap peningkatan kadar hemoglobin.

\section{SIMPULAN}

Ada pengaruh pemberian kukis pelangi ikan gaguk terhadap remaja putri di MTs Pancasila Kota Bengkulu sebelum dan sesudah dengan $p$ value $<0,05$ yakni 0,000 . Rata-rata recall remaja putri 3x24 jam yaitu asupan Fe sebesar 5,40mg, asupan vitamin $\mathrm{C}$ sebesar $5,7 \mathrm{mg}$ dan asupan protein sebesar 40,4gram. Perlu dilakukan pemeriksaan feritin dan transferin pada penelitian selanjutnya. 


\section{DAFTAR PUSTAKA}

Adriani, M., dan Wirjatmadi B. (2012). Pengantar Gizi Masyarakat. Jakarta: Kencana Prenada Media Group.

Almatsier, S. (2009). Prinsip Dasar Ilmu Gizi. Jakarta: PT Gramedia Pustaka Utama.

Almatsier, S. (2011). Gizi Seimbang Dalam Daur Kehidupan. Jakarta: PT. Gramedia Pustaka Utama.

AKG. (2019). Permenkes RI No 28 Tahun 2019 tentang Angka Kecukupan Gizi yang Dianjurkan Untuk Masyarakat Indonesia. Menteri Kesehatan RI, Jakarta.

Diah, D., Kristianto, Y., Rullyni, N. T., Ridayani, R., \& Rahmadona, R. (2019). Pengaruh Otak-Otak Tempe Bilis terhadap Kadar Haemoglobin $(\mathrm{Hb})$ Ibu Hamil dengan Anemia. Quality: Jurnal Kesehatan, 13(2), 54-61.

Dona, Astuti. (2014). Pengaruh pemberian fe dan vitamin $\mathrm{c}$ terhadap peningkatan hemoglobin pada remaja putri yang mengalami anemia di SMPN 1 Baso Kabupaten Agam tahun 2013. [Skripsi]. Padang: Fakultas Kesehatan Masyarakat, Universitas Andalas.

Febrianti, S. (2013). Analisis Faktor-Faktor Yang Memengaruhi Harga Ikan Manyung (Arius thalassinus) Di TPI Bajomulyo Juwana Pati. Journal of Fisheries Resources Utilization Management and Technology, 2(3), 162-171.

Indrawani, Yvonne M \& Arfiyanti. (2010). Peningkatan Pengetahuan Mahasiswa Kedokteran Tentang Suplementasi Makanan pada Ibu Hamil yang Anemia: Fortifikasi cookies dengan vitamin, mineral, ligan, albumin, dan globin. [Skirpsi]. Depok: Fakultas Kedokteran, Universitas Indonesia.

Jaelani, M., Simanjuntak, B. Y., \& Yuliantini, E. (2017). Faktor Risiko yang Berhubungan dengan Kejadian Anemia pada Remaja Putri. Jurnal Kesehatan, 8(3), 358-368.

Kementerian Kesehatan RI. (2013). Riset Kesehatan Dasar Tahun 2013. Jakarta: Badan Penelitian dan Pengembangan Kesehatan.

Kementerian Kesehatan RI. (2018). Riset Kesehatan Dasar Tahun 2018. Jakarta: Badan Penelitian dan Pengembangan Kesehatan.

Lailiyana. (2012). Analisis Kandungan Zat Gizi dan Uji Hedonik Kukis Kaya Gizi pada Siswi SMPN 27 Pekanbaru. [Skripsi]. Depok: Universitas Indonesia.

Mansur, W. (2017). Pengaruh Pemberian Brownies Tempe Subtitusi Wortel (Daucus
Carota L.) Terhadap Kadar Hemoglobin (Hb) Pada Ibu Hamil Anemia Di Wilayah Kerja Puskesmas Pertiwi Kecamatan Mariso Kota Makassar Skripsi Diajukan Untuk Memenuhi Salah Satu Syarat Meraih Gelar. [Skripsi]. Makassar: Universitas Islam Negeri Alauddin Makassar.

Maryam, Siti. (2016). Gizi dalam Kesehatan Reproduksi. Jakarta: Salemba Medikal

Putri, R. D., Simanjuntak, B. Y., \& Kusdalinah, K. (2017). Pengetahuan Gizi, Pola Makan, dan Kepatuhan Konsumsi Tablet Tambah Darah dengan Kejadian Anemia Remaja Putri. Jurnal Kesehatan, 8(3), 404.

Quintero-Gutiérrez, A. G., Mariaca-Gaspar, G. I., Villanueva-Sánchez, J., Polo, J., Rodríguez, C., \& González-Rosendo, G. (2012). Acceptability and use of heme-iron concentrate roduct added to chocolate biscuit filling as an alternative source of a highly available form of iron. CYTA Journal of Food, 10(2), 112-118.

Sri, Dewi Kartika. (2014). Efikasi pemberian biskuit fungsional ikan gabus (ophiocephalus striatus) terhadap imunitas humoral anak. [Disertasi]. Bogor: Institut Pertanian Bogor.

Sari, H. P., Agustia, F. C., Subardjo, Y. P., \& Ramadhan, G. R. (2018). Biskuit mocafgarut tinggi zat besi meningkatkan kadar Fe darah dan kadar hemoglobin pada tikus Sprague Dawley. Jurnal Gizi Indonesia (The Indonesian Journal of Nutrition), 7(1), 49-53.

Sediaoetama, A. D. (2010). Ilmu gizi untuk mahasiswa dan profesi. Jakarta: Dian Rakyat.

Setyaningsih RI, Pangestuti DR, Rahfiludin MZ. (2018). Hubungan asupan protin, zat besi, vitamin $\mathrm{C}$, fitat dan tannin terhadap kadar hemoglobin calon pendonor darah lakilaki. Jurnal Kesehatan Masyarakat, 8; 6(4): 238-246.

Simanjuntak, B. Y. (2006). Pengaruh Suplementasi Tablet Besi 2 Kali Seminggu Selama 12 Minggu dan Faktor-Faktor yang Berhubungan dengan Status Anemia Siswa di 6 SD Jakarta Utara. [Thesis]. Depok: Universitas Indonesia.

Syahwal, S., \& Dewi, Z. (2018). Pemberian snack bar meningkatkan kadar hemoglobin (Hb) pada remaja putri. AcTion: Aceh Nutrition Journal, 3(1), 9-15.

Vitando, T., Simanjuntak, B. Y., \& Jumiyati. (2019). Perubahan Kadar Protein dan Kalsium pada Pembuatan Tepung Ikan 
Gaguk dengan Variasi Suhu dan Waktu [Karya Tulis Ilmiah]. Bengkulu: Polteknik Kesehatan Kemenkes Bengkulu.

World Health Organization (WHO). (2017). Global Accelerated Action for the Health of Adolescents (AH-HA): guidance to support country implementation. Geneva: World Health Organization.

World Health Organization (WHO). (2011). Guideline: Intermittent Iron and Folic Acid Supplemention in Menstruating Women. Geneva: World Health Organization. 